\title{
A Caribbean Affair: The Liberalisation of the Slave Trade in the Spanish Caribbean, 1784-1791
}

\author{
José Luis Belmonte Postigo \\ Universidad de Sevilla. Facultad de Geografía e Historia. \\ Departamento de Historia de América. \\ C/ Doña María de Padilla, s/n, 41004 Sevilla \\ e-mail: jbelmonte@us.es \\ ORCID iD: http://orcid.org/0000-0002-9061-4625
}

Submitted: 07 October 2018. Accepted: 03 February 2019

\begin{abstract}
The liberalisation of the slave trade in the Spanish Caribbean ended with a series of political measures which aimed to revitalise the practice of slavery in the region. After granting a series of monopoly contracts (asientos) to merchant houses based in other western European nations to supply slaves to Spanish America, the Spanish monarchy decided to liberalise import mechanisms. These reforms turned Cuba, especially Havana, into the most important slave trade hub within the Spanish Caribbean. Havana was connected with both Atlantic and inter-colonial trade networks, while other authorised ports imported slaves from other Caribbean territories; Spanish, British, Dutch, Danish and American traders all participated in this trade, and slave trafficking became the most profitable form of commerce in the region during this period.
\end{abstract}

KEYWORDS: Atlantic Slave trade; Intercolonial trade; Cuba; Venezuela; Puerto Rico; Santo Domingo.

Citation / Cómo citar este artículo: Belmonte Postigo, José Luis (2019) "A Caribbean Affair: The Liberalisation of the Slave Trade in the Spanish Caribbean, 1784-1791". Culture \& History Digital Journal, 8 (1): e014. https://doi.org/10.3989/ chdj.2019.014

RESUMEN: Un asunto caribeño. La liberalización del comercio de esclavos en el Caribe hispánico, 1784-1791.La liberalización del comercio de esclavos en el Caribe hispánico culminó una serie de medidas políticas que trataron de revitalizar el esclavismo en la región. Tras firmar dos contratas para el abastecimiento de esclavos, la monarquía española decidió flexibilizar los mecanismos para su introducción. Esta política confirmó a Cuba, especialmente a La Habana, como la región esclavista más importante. Mientras La Habana estuvo conectada al comercio atlántico de esclavos, además de a circuitos intercoloniales, el resto de puertos habilitados obtuvieron sus esclavos de otros territorios caribeños, gracias al aporte de comerciantes españoles, británicos, holandeses, daneses y estadounidenses, constituyéndose este comercio regional como dominante en este periodo.

PALABRAS CLAVE: Comercio atlántico de esclavos; Comercio intercolonial; Cuba; Venezuela; Puerto Rico; Santo Domingo.

Copyright: (C) 2019 CSIC. This is an open-access article distributed under the terms of the Creative Commons Attribution 4.0 International (CC BY 4.0) License.

On May 17 1789, the English frigate Mosley Hill, captained by Joseph Fayrer, moored in La Guaira. Between 1785 and 1789, the ship had undertaken four voyages to and from harbours such as Bonny in West Africa and La Guaira, Trinidad, and Havana. ${ }^{1}$ These voyages followed the granting of asiento to the Liverpool-based trading house Baker and Dawson, ${ }^{2}$ which owned the ship. The ship had left the coast of Benin and, after touching at Trinidad, sailed straight to La Guaira. There, the captain, along with the Liverpool company's representative, Phil- 
ip Langton, approached the Intendente of Caracas, Juan Gillelmi, to ask whether the 453 slaves in the ship's hold could be considered part of the recently expired asiento. On February 28 1789, the liberalisation of the market had brought Baker and Dawson's to an end, but conditions established in the terms of the agreement were to still apply to Baker and Dawson ships that had left Europe before the date of the proclamation. Once the Intendente confirmed that the contract still applied to the Mosley Hill's enslaved Africans, Baker and Dawson's representatives asked him to summon local landowners to whom they could sell the slaves. Neither Fayrer nor Langton were willing to risk unloading the slaves before the buyers were guaranteed. The meeting took place, but the results were not as expected because the hacendados from Caracas demanded be allowed to buy the slaves on credit, with the money to be paid in instalments, offering neither precious metal nor other assets as a guarantee. As a result, Fayrer and Langton decided to set sail for Havana, the main slave market in the Spanish Caribbean, where they hoped to sell their cargo.

Fayrer's decision is neither surprising nor unprecedented; along with William Forbes, the skipper of the frigate Garlant, he had previously gone to Havana to sell those slaves that could not be sold in La Guaira. These expeditions linked the three main locations in the Spanish Caribbean where Baker and Dawson introduced slaves from 1784 onwards. In late 1788, the demands of the Havana oligarchy, which was tremendously influential in Madrid, drove the monarchy to refuse to renew the asiento and to liberalise the slave trade in the ports of Havana, Santiago de Cuba (in this case, for Spanish ships only), Santo Domingo, San Juan de Puerto Rico and, La Guaira and Puerto Cabello, in the Province of Caracas. This measure opened up free trade links between Spanish territories, and their main slave-supply regions, which were located in 'neighbouring foreign colonies' rather than on the western coast of Africa.

The Liberalisation of the slave trade proclaimed in February 1789 provided a major boost to the slave trade, significantly increasing the number of arrivals. Cuba profited more than any other territory from this measure, since it absorbed most of the new arrivals. In addition, the liberalisation of the trade suppressed the barriers that other colonial powers had faced before this date. In fact, the new legal framework legitimised and regulated previous contraband practices, which played a crucial role in maintaining the cohesion of the Caribbean. Jamaica, Dominica, Saint Thomas, and Saint Croix, among others, became the main suppliers of slaves to the Spanish territories, acting as middlemen between the Spanish Caribbean and the West African coast (O’Malley, 2014: 271).

Havana, however, was an exception to this general model because it served as a hub for both inter-Caribbean commercial circuits and for French slave merchant with Africa $\mathrm{s}$ who traded in Africa.n -Caribbean commercial circuits and for British, American, and to a 1British, American, and French slave merchants arriving directly from Africa (similar developments would take place later in the Río de la Plata). This paper argues that the coexistence of Caribbean and Atlantic slave routes was essential in keeping up with Havana's high demand for slaves, and this turned the city into the main slave market in the Spanish Caribbean. Although other territories were also affected by the liberalisation process, they never experienced a commensurate development of the slave trade system. The arrival of slaves to the Spanish Caribbean was made possible through the combined actions of British agents, Americans (connected with Atlantic networks) and, especially, Spanish buyers, who acquired slaves in colonies such as Jamaica, Dominica, Curaçao, and the Danish West Indies (O'Malley and Borucki, 2017: 315338). The arrival of slaves directly from Africa chiefly affected the port of Havana, although, most of the slaves arriving in Cuba came from other Caribbean dominions. Spain's inability to establish direct supply centres in West Africa strengthened regional Caribbean trade circuits, in which Spanish merchants played a major role, albeit not a dominant one, largely as purchasers of slaves (Pearce, 2014).

\section{SEEKING A PANACEA: SPANISH DEPENDENCE ON BRITISH TRADERS}

The end of the War of Jenkins' Ear had serious repercussions for Spanish policies regarding slavery. A few years after this event, in 1750, Spain and Great Britain signed the Treaty of Madrid, which brought the British asiento to an end (Donoso, 2007: 105-144). During this same year, the Spanish monarchy decided to stop returning fugitive slaves to Britain and Holland (their main competitors during the war), thereby transforming transimperial marronage into a tool for international diplomacy (Rupert, 2013:199-232; Belmonte, 2017: 43-70; Aizpurúa, 2008: 81-94). These measures aimed to rid Spain of its previous dependence on British slave suppliers. When the British asiento had been in force, however, Jamaica had played a major role in the intra-regional slave trade to Cuba as the main redistribution centre for slaves who had survived the Middle Passage (García Rodríguez, 2008: 189-214). Thus the implementation of the monarchy's new policy was riddled with difficulties from the start. The creation of the Compañia Gaditana de Negros, in 1765 , was the most daring attempt to create a trade structure that could operate independently of the major British dealers. However, its inability to acquire slaves directly from West Africa, along with the unwise decision to establish the company's headquarters in San Juan de Puerto Rico, where demand for slaves was significantly lower than in other territories such as Cuba, made the company unviable. Its bankruptcy forced the monarchy to reach a series of compromises in order to save the project. The company was restructured with an increased capital base thanks to investments from Cuban merchants, such as Enrile, who moved the company's headquarters to Havana in $1773 .{ }^{3}$ Between 1773 and 1779 , the number of slaves arriving in Havana increased significantly, largely owing to the high demand for slave labor 
in Havana's hinterland, the active participation of Havana and Cádiz merchants, and the increasing demand for sugar from the English-speaking North American colonies, which in turn greatly boosted Cuban sugar production (Tornero, 1996: 38).

In any case, none of these measures could stop the ongoing contraband trade, especially in the Spanish Greater Antilles. In 1770, the Spanish monarchy forced the authorities in Cuba, Santo Domingo and Puerto Rico to $c a-$ rimbear - to brand - all slaves coming through their ports, as a way of proving that all due taxes and duties had been paid. Slave owners were also encouraged to prosecute the owners of unbranded slaves. In San Juan, Puerto Rico, this measure revealed the existence of a network of slave smugglers, led by two custom officers who had made duplicate 'branding irons', ${ }^{4}$ thus forcing the authorities to design new brands, years later, to prevent fraud. ${ }^{5}$ In Santo Domingo, the authorities began inspecting slaves more carefully, and the number of unbranded slaves turned out to be so large that the Dominican officials asked Madrid to issue a general pardon. ${ }^{6}$ Ending the trade in 'smuggled negroes' proved virtually impossible, despite adjustments to the supply system in the Greater Antilles. After1778, the Spanish slave trade project acquired a new asset. With the purchase of Fernando Poo and Annobon, two erstwhile Portuguese dominions in West Africa, the Spanish monarchy attempted to establish commercial centres from which to buy slaves directly (García Cantús, 2004: 73-101). However, the paucity of pre-existing colonial structures in these territories, the local populations' resistance to the Spanish invasion, and environmental difficulties, especially illness, hampered Spanish attempts to establish an efficient commercial system. These political and commercial measures also clashed with the main geostrategic interests of the monarchy. In 1779, Spain's intervention in the American War of Independence further hamstrung Spanish measures to establish a commercial system that could operate independently of the major British merchants. During the conflict, the Spanish authorities extended specific licences to dealers who, in defiance of the terms of these licences, continued to operate mostly from French Caribbean territories.

The end of the war left deep scars on British Caribbean dominions. The independence of the United States led to American traders' expulsion from most British commercial circuits. In the Caribbean, this meant severing ties with territories with which Britain had maintained close bonds, and which had played a major role in the expansion of slavery in the Antilles, for instance by supplying the food for the embarked slaves. In this context, Edward Barry, a representative of Fitch and Company, a trading house that specialised in redistributing goods throughout the Caribbean (O'Shaughnessy,2000: 228), began to negotiate a slave trade contract in 1784 . The company was to import 4,000 slaves from Africa to Trinidad, and then from Trinidad to Venezuela, at 150 pesos apiece. In addition to providing tax exemptions, the proposal specified that payment could be effected with cattle, which gave the company a monopoly over the cattle trade between Trinidad and Jamaica. ${ }^{7}$

As negotiations progressed, Edward Barry signed an agreement with John Black, from Trinidad, with whom he created the company Barry \& Black. Barry was to hold the asiento under the same conditions agreed upon earlier when he had represented Fitch and Company. Almost simultaneously, both Edward Barry and John Black were given full powers as agents of Baker and Dawson (Piqueras and Vidal, 2018: 88). Based in Trinidad, Barry and Black were to provide facilities for holding slaves after the Middle Passage, as well as to organise expeditions to La Guaira. As far as Spanish authorities were concerned, the contractor was Edward Barry, who acted as a member of Barry \& Black and an agent of Baker and Dawson. In practice, the contract was exploited by Barry, who, alongside the captains, seamen and ships employed by Baker and Dawson, met the conditions of the agreement. ${ }^{8}$ At the same time, Baker and Dawson gained indirect access to Spanish Caribbean market (Borucki, Eltis, and Wheat, 2015:450).

The ships sailed from the Bight of Biafra, landing first at Trinidad, ${ }^{9}$ then sailing for La Guaira, where the slaves were sold. Payment was not made in La Guaira, but in Havana, where the slave ships had to sail to collect their proceedings after having received libranzas (orders of payment) from the Intendente in Caracas. ${ }^{10}$ Mexican silver was used in Havana to pay for slaves brought from Biafra and sold in Caracas. Ultimately, most of this silver found its way to Liverpool, which reflects the complexity of the slave trade during this period, and the multiplicity of agents involved. The system is also a reflection of the Spanish monarchy's willingness to galvanise the slave trade, which benefited from all the resources of the imperial system (extraction and coining of silver from the mines of New Spain, delivery of this silver to Havana and the establishment of a single account for the slave trade at the regional level). The financial effort made by the Real Hacienda (royal treasury), which was ultimately the body that paid the English slave dealers in cash, made it possible for the slave system to thrive, boosting demand and establishing the productive and mercantile structures that supported the large-scale Spanish slave trade after 1808.

The choice of Trinidad as the initial point of disembarkation responded to the need to establish a resting point for the captives and a control point to prevent contraband (Borucki, 2012: 41-42). Throughout the second half of the $18^{\text {th }}$ century, a frenzy of slave trafficking in the ports of Old Calabar and Bonny had transformed Biafra into one of the primary areas of activity for the main British slave dealers (Rawley, 2005: 186). Until then, the area had played no more than a marginal role in the British trade, although ethnic conflicts, which were encouraged by European merchants (Nwawa, 1990: 227-245), and the introduction of more efficient trade transaction systems (Lovejoy and Richardson, 1999: 333-355), eventually facilitated the deployment of larger ships. This resulted in the massive arrival of so-called 'carabali' slaves to Spanish dominions. The island's inclusion in the Atlantic slave 
trade stimulated commerce, thus attracting new settlers, which in turn improved the island's defensive position. Almost simultaneously, the monarchy passed a decree offering incentives to new settlers, including foreigners, in order to revitalise Trinidad's economy. ${ }^{11}$

Baker and Dawson's solvency opened the door to their gaining a new contract, once the one negotiated by Edward Barry had expired. This new asiento, which was directly negotiated by John Dawson and Peter Baker, opened the system to the harbour of Havana, in addition to La Guaira, and paved the way for extending it to the port of Santo Domingo too. ${ }^{12}$ The last point was not compulsory and depended on the ability of the authorities in Caracas to convince the ship captains to enter La Guaira and transport a limited number of slaves to Santo Domingo. The monarchy's target was to bring 2,300 slaves to Havana, 1,200 to La Guaira and 1,000 to Santo Domingo every year. ${ }^{13}$ Finally, Baker and Dawson's reluctance led Santo Domingo authorities to withdraw from the agreement. ${ }^{14}$

The 1786 asiento aimed to guarantee supply of slaves in the regions where demand was greatest: in Cuba, through the harbour of Havana, and the Province of Caracas, with La Guaira as the main port of arrival. ${ }^{15}$ The agreement was a tacit recognition of Spain's inability to create an independent system capable of meeting the demand for slaves that the Bourbon Crown was, at the same time, stimulating (Schneider, 2015: 3-29). The new contract made no mention of Barry \& Black, which had acted as a middleman for the previous contract. ${ }^{16}$ It specified that the slaves were to be sold at 155 pesos apiece, and placed the British company and its ships' captains at the heart of the system. ${ }^{17}$

Havana-bound ships had to arrive directly from Afri$\mathrm{ca}$, without landing at any Caribbean harbour. ${ }^{18}$ By insisting on these terms, the elite of Havana were trying to prevent potential competition posed by hacienda owners in Caracas, although the increased length of the voyage could result in higher levels of illnesses and mortality aboard ship. Prior to the period of liberalisation, slavery had not been synonymous with plantation labor in Cuba (De la Fuente, 2009: 147-149), Caracas (Quintero, 2013:240-256), Santo Domingo (Widmer, 2003:143-158) or Puerto Rico (Caamaño, 2012: 195-224). According to the testimony of their respective representatives, one of the main problems suffered by each of these regions was a shortage of labour. For this reason the Bourbon monarchy went to considerable lengths to promote the slave trade.

Also in 1786, the monarchy liberalised the slave trade system for the first time, although only for Santo Domingo, a port that had proven difficult to effectively include in previous asientos. This measure was part of a package of commercial and fiscal measures which aimed to revitalise the colony's economy (Gutiérrez Escudero, 2010: 93). The model that the monarchy was trying to create included the promotion of export agriculture, and the regulated importation of slaves (Cassá, 2003: 246-249). Until that time, the complementary nature of the two colo- nies that shared the island had resulted in a set of economic interactions that included both legal and illegal slave sales (Moya Pons, 2008: 150-152; Belmonte, 2016). Informal trade, which was sometimes accepted and often tolerated, was enough to meet the demand, thereby hampering the development of a more efficient system for importing slaves.

This partial liberalisation in Santo Domingo was a resounding fiasco, either because the demand for slaves was not high enough and was easily met by the neighbouring French colony, or because the incentives to sell slaves were not sufficient to attract slave merchants. Santo Domingo's production of sugar and cocoa, which were very profitable goods owing to European demand, was negligible (Sevilla Soler, 1981: 137-148). Although the promotion of tobacco production in the past had lead to a modest increase in production, it remained a royal monopoly, and was earmarked for the Crown's factories in the Iberian Peninsula (Gutiérrez Escudero, 2011:1-13). The colony's mercantile and financial structure was also too poorly developed to support purchases on credit, thereby hampering Santo Domingo's ability to raise its profile in the slave trade. ${ }^{19}$

\section{PROBLEMS WITH THE ASIENTO: THE ROAD TO LIBERALISATION}

The liberalisation of the slave trade in Santo Domingo did not meet expectations, and Baker and Dawson's asiento brought thousands of slaves, mostly from the Bight of Biafra (carabalies), to Cuba and Venezuela, where they were employed in the largest haciendas. However, some problems began to arise that brought the system's viability into question, especially in Cuba. The fact that Havana was the only harbour on the island open to the slave trade caused great unrest in Santiago de Cuba, where the demand for slaves had increased during the second half of the $18^{\text {th }}$ century. In order to buy slaves legally, Santiago hacienda owners had to travel to Havana, and the added transport expenses considerably increased their costs (Belmonte, 2010: 445-468). The landowners' complaints fell on sympathetic ears in Madrid; the Crown was aware that successful implementation of the system required suppressing all incentives to deal in contraband (Schneider,2019). For this reason, the Baker and Dawson ship, the Joven Héroe, was allowed to moor in eastern Cuba, where she sold 190 of the 205 slaves she carried aboard (Belmonte, 2012: 144).

In Havana, some arguments began to be uttered against the British company's performance: there were complaints about the poor health of the slaves brought to the island, and it was argued that they did not meet the high level of "quality" demanded by the contract. Some also complained about overpricing and contraband activities. ${ }^{20}$ The increasingly loud voices that argued against the renewal of Baker and Dawson's contract were orchestrated by advocates of the liberalisation of the market in Havana and Madrid. As the end of the two-year contract loomed nearer, their wishes were initially frus- 
trated when the Crown granted a six-month extension to the company. ${ }^{21}$

José Antonio Piqueras points out that the mouthpiece of Havana's oligarchy, Francisco de Arango y Parreño, had been very active in Madrid, calling attention to the advantages that would follow the liberalisation of the slave market (Piqueras, 2009a: 164-165). In addition to denouncing alleged irregularities, the hacienda owners argued that renewing the asiento would be against the interests of the Crown, as it ultimately resulted in an unacceptable transfer of funds to a rival power. In the midst of these political moves, Baker and Dawson offered to sign a new contract in 1788, triggering an energetic reaction against it from Havana's oligarchy (Piqueras, 2009b: 273-277). At any rate, regardless of political and economic rivalries within the complex Cuban environment, it seems that some of the complaints issued by Havana's oligarchs were fully justified, especially in the early days of the asiento, and that many of the slaves coming straight from West Africa were returned (see Table 1).

Slaves could be returned for many reasons. They could be in ill health after the Middle Passage or simply not meet the standards expected by hacienda owners or specified in the asiento. Astigarreta's report is interesting in this regard: of the 4,939 slaves imported by Baker and Dawson, 3,104 (62.8\%) were men, and 1,835 women $(37.2 \%) ; 626$ men were returned $(20.1 \%$ of the total), compared to as many as 777 women $(42.3 \%) .{ }^{26}$ Therefore, gender seemed to be a key factor in the rejection of slaves.

In contrast to normal practices elsewhere on the West African coast, the number of women who embarked in Old Calabar, especially Bonny, was relatively high. In Bonny, females slaves accounted for $46 \%$ of the total (37.8\% if only adult women are taken into consideration). Nwokeji (2010: 154-161) argues that this was because the Biafran women played a negligible role in agricultural practices. As such, the demand for female slave labour in the hinterland of the Bight of Biafra was low, in contrast to other African regions, thereby facilitating their inclusion in the major British slave trade circuits.

Sex ratios aboard Baker and Dawson ships reflected this trend, but this did not go over well in Cuba; where it was considered acceptable for women to account for onethird of the captives aboard a slave ship, a proportion which sufficed to cover the demand for female labour. ${ }^{27}$ The arrival of a larger proportion of women caused some reservations among Cuban slave owners, and also in Madrid, which had been trying to develop export agriculture in the Caribbean. As was the case in many other Caribbean cities, the role of slave women as domestic servants was essential; often, these slaves were bought by free women, whose participation in the economic system based on slavery kept them in a good social and economic position, despite their legal limitations (Fuentes, 2016: 75). This was, however, of little concern

TABLE 1. Slaves imported by Baker and Dawson through Havana, 1786-1789.

\begin{tabular}{|c|c|c|c|c|c|}
\hline Name of the ship & $\begin{array}{l}\text { Date of } \\
\text { arrival }\end{array}$ & Region of origin & $\begin{array}{l}\text { Slaves delivered, } \\
\text { according to } \\
\text { slavevoyages.org }\end{array}$ & $\begin{array}{c}\text { Slaves delivered, } \\
\text { according to AGI, } \\
\text { Indiferente General } \\
\mathbf{2 8 2 2} \\
\end{array}$ & $\begin{array}{c}\text { Slaves returned, } \\
\text { according to AGI, } \\
\text { Indiferente General } \\
2822\end{array}$ \\
\hline Héroe & $06 / 07 / 1786$ & Cameroon & 210 & 210 & 0 \\
\hline Campeón & $14 / 08 / 1786$ & Bonny & 406 & 217 & 189 \\
\hline Princesa Real & $08 / 10 / 1786$ & Bonny & 700 & 230 & 303 \\
\hline El Príncipe & $22 / 10 / 1786$ & Bonny & 92 & 55 & 37 \\
\hline Mosley Hill $^{22}$ & $09 / 05 / 1787$ & Caracas & 0 & 8 & 0 \\
\hline Princesa Real & $08 / 10 / 1787$ & Bonny & 731 & 339 & 385 \\
\hline Garland & $29 / 10 / 1787$ & Caracas & 114 & 35 & 0 \\
\hline Héroe & $17 / 03 / 1788$ & Benin & 450 & 321 & 128 \\
\hline Dos Hermanos & $02 / 04 / 1788$ & Bonny & 610 & 429 & 176 \\
\hline Princesa Real & 09/09/1788 & $\begin{array}{c}\text { Africa } \\
\text { (no details given) }\end{array}$ & 706 & 550 & 156 \\
\hline Garland $^{23}$ & $13 / 01 / 1789$ & Bonny & 328 & 444 & 0 \\
\hline Dos Hermanos ${ }^{24}$ & $28 / 03 / 1789$ & $\begin{array}{c}\text { Africa } \\
\text { (no details given) }\end{array}$ & 383 & 367 & 16 \\
\hline Héroe & $30 / 03 / 1789$ & $\begin{array}{c}\text { Africa } \\
\text { (no details given) }\end{array}$ & 360 & 331 & 13 \\
\hline TOTAL & & & 5,090 & 3,536 & 1,403 \\
\hline
\end{tabular}

Source: Slavevoyages.org; and AGI, Indiferente General 2822. ${ }^{25}$ 
to the monarchy, whose efforts were focused on developing the export agriculture sector. In the belief that women could not withstand the heavy labour involved in plantation agriculture, the arrival of female slaves was considered detrimental, and it was even forbidden temporarily in the harbours of Havana and Caracas, ${ }^{28}$ although this order was eventually revoked. ${ }^{29}$

The fact that slave owners in Havana rejected slaves at a time when the demand was high raises a series of questions. The most important of these is what happened to those for whom no buyer could be found. Captains had the right to sell these slaves informally within eight days of the formal sale of the rest of the captives. ${ }^{30}$ This was an attractive option for slave dealers, who could thus recover some of their investment. Another option was to sell the slaves clandestinely in second- or third-rate harbours, which were barely within, if not totally outside, governmental control (Karras, 2007: 121-133). Similarly, we cannot rule out that at least some of these slaves were sent to Jamaica, where Baker and Dawson had close associates, and whence they could be redistributed to other Caribbean regions or, simply, sold to Jamaican buyers.

Havana's oligarchy was not alone in asking for the end of the contract; similar petitions were being raised all over the Spanish dominions, from Louisiana to the viceroyalty of New Granada. Baker and Dawson, for their part, insisted on the necessity of signing a new asiento, committing to import yet more slaves at reasonable and stable prices. Finally, the Junta Suprema de Estado met to make a determination and decided that, given the shortage of labour, more resources and a new system should be implemented to guarantee the supply of slaves. The Junta decried Spain's inability to create permanent commercial relations in West Africa, as had been done by the British, the French and the Portuguese. The Junta also declared that Spanish Louisiana merchants' idea of creating direct links with Africa was potentially interesting but needed time. However, time was in short supply, given the urgency of the demands coming from Caracas and Havana.

The Junta was also sympathetic to the complaints of Cuban hacienda owners, who had pointed out that, while the contract had facilitated the arrival of a large number of slaves, it also led to an increase in contraband and fraud against royal revenues. For these reasons, the Junta decided to extend the period of grace given to Santo Domingo in 1786 and to liberalise the slave traffic as the best way of promoting export agriculture and trade. ${ }^{31}$ The Baker and Dawson's request was rejected, and the slave trade to Cuba, Santo Domingo, Puerto Rico and the Province of Caracas was liberalised on February 28, 1789.

\section{PROBLEMS WITH AND SOLUTIONS FOR THE LIBERALISED SLAVE TRADE}

The liberalisation of the slave trade was not the end of Baker and Dawson's activities. From April 1789 to December 1790, their ships Benjamin, Blaydes, Two Broth- ers, Héroe and Thomas arrived in Havana with enormous slave cargoes. ${ }^{32}$ The main difference was that harbours which had hitherto been virtually closed to the slave trade were now open to British, French, Danish and Spanish slave merchants. Most of the slaves were brought from other Caribbean islands with strong commercial links to Havana, despite being owned by rivals of the Spanish monarchy. The new rules of the slave trade encouraged and legitimised a set of commercial relationships that had long played a crucial structural role in the region, often in abeyance of legal restrictions. Far from trying to flush foreign merchants out of the slave trade system, Spanish authorities endeavoured to recruit all possible resources for their project, encouraging their operation in nearly every port. The only exception was Santiago de Cuba, which was open only to Spanish ships. The close commercial bonds that existed between the eastern Cuban capital and various ports in Jamaica, such as Kingston and Montego Bay, were the reason behind this exception, which was an attempt to prevent contraband from getting out of hand.

The new rules generated doubts and concerns which local authorities promptly relayed to Madrid. Between 1789 and November 1791, when the trade's liberalisation came into full force, various reports from Havana, Caracas, San Juan and Santo Domingo were sent to the peninsula in order to clarify a number of grey areas. In Santo Domingo, where not a single slave had arrived legally since the liberalisation of the trade, the main concern referred to point 8 of the new regulations. In this point, the king had stated that the aim of the legal change was to promote agriculture, and that slave owners who did not put their slaves to work on haciendas were to be penalised by 2 pesos per year. ${ }^{33}$ The concerned Santo Domingo city council asked Madrid whether this measure was to be applied retroactively. The governor of Santo Domingo, Joaquín García, reminded the Crown that the liberalisation of 1786, which concerned the import of tax free slaves, had not had the desired effects, owing to the ruinous state of the colony. Should this measure be implemented, he claimed, the citizens of the colony would suffer, and no one would profit other than foreign merchants (who were the only merchants capable of sending slaving voyages to Santo Domingo).

The governor also pointed out that slaves were needed in the colony, although he admitted that most of them were employed as domestic servants, shepherds and hired workers. The new regulations were an attempt to change this situation. Stock-keeping, domestic service and other trades, especially in urban contexts, were profitable for slave owners, but generated little royal revenue. For this reason, the Crown decided to 'encourage' slave owners by means of taxation, prompting them to put their slaves to work in sectors where there was a large international demand. Royal authorities clarified that this applied only to those slaves imported within the framework of the new norms, not retroactively, while also indicating that it was desirable to limit the number of domestic slaves and those used as hired workers. ${ }^{34}$ 
In San Juan, Puerto Rico, Antonio Liyá, captain of the schooner San José y las Ánimas, claimed to have brought in four slaves who were being employed on a sugar estate owned by his ship's owner. After paying the compulsory duties, he attempted to claim his money back because he had complied with the new regulations. This petition was rejected on the grounds that fiscal exemptions were applicable only to ships loading slaves - and only slaves in foreign colonies, whereas Liyá had imported additional 'goods', rendering him ineligible for a return. With this measure, the authorities were trying to curtail contraband activities from taking place under the umbrella of slave trading. In order to avoid fraud, the governor of Puerto Rico arranged for heavy sanctions to be applied to slave ships that landed at bays or other mooring points before entering the city's port. In addition, in order to prosecute smugglers and to calculate the number of slaves being employed in domestic service or in non-agricultural trades, the governor compelled the district mayors in San Juan and military officials in the rest of the island to carry out periodical censuses, carefully recording slaves who worked outside haciendas. ${ }^{35}$

In Caracas, the new regulations prompted the Intendente Guillelmi to ask for clarification regarding different factors that could have an effect on the normal operation of the slave trade. Guillelmi asked whether the limits of the province were the same as those of his Intendencia; in other words, whether Maracaibo, Barinas, Cumaná, Trinidad and the island of Margarita were authorised to take part in the new system. In his opinion, by authorising only La Guaira and Puerto Cabello, other provinces were prevented from benefiting from the new system. The Intendente suggested that Cumaná, Nueva Barcelona and Maracaibo be included, thereby allowing the whole country to benefit from the importation of slaves brought from 'foreign colonies'. Guillelmi was also concerned about the taxes to be levied on local (Spanish American) slave merchants, especially given the expenses involved in bringing slaves from other colonies. ${ }^{36}$ Along the same lines, the Intendente also expressed doubts about the type and quality of the products that could be used as payment for the new workforce. The reply from Madrid was that products fell into two categories: those which were of interest to Spanish trade, and those which were not. In the Crown's opinion, products such as cocoa and indigo, which were in high demand among Spanish merchants, should on no account be used to buy slaves because this would severely undermine Spanish merchants based in Cádiz. The metropolitan authorities pointed out that this decision would increase contraband, but that this would be compensated by the increase in agricultural production.

Guillelmi was also concerned about the "quality" of the slaves arriving in Venezuela. The Intendente pointed out that article six of the new regulations clearly established that slaves of 'bad breed' were to be rejected. Noting that carabalies were famous for their allegedly superstitious (agorera) nature, Guillelmi suggested treating them like 'the disabled, the ill, or those suffering from the usual malaises'. Madrid's response was that a slave could be "agorero" and still work very hard, and that the decision should ultimately fall to the experts, namely the hacienda owners. The government's only duty was to prevent the arrival of ill slaves, and the selection of enslaved workers should be left to merchants and slave owners. ${ }^{37}$ The Intendente's questions may have been a subtle way of trying to get rid of the British merchants, who controlled the trade from Biafra.

In Havana, the main doubts revolved around the tax to be applied to slaves working in non-agricultural occupations: was the tax to be applied retroactively? Was it the same for men and women, and for slaves living in the city as opposed to the countryside? Finally, did it apply to slaves labouring on public works? ${ }^{38}$ After ruling out retroactivity, the Junta de Estado decided that since women were less necessary in agriculture but constituted most of the domestic workers, where they were the main support of 'honest families and widows', they should be either exempt from the tax or pay only half. ${ }^{39}$

In Santiago de Cuba the arrival of the French brig El Soberbio from Dominica with 197 slaves on board caused a conflict between the governor of Santiago and the island's Capitán General. The ship, captained by Jean Couture, was on its way to Havana when contrary winds and some technical problems forced her to dock in Santiago. While the ship was being repaired, Couture asked permission to sell some of the slaves he carried aboard, and the governor consented, sending copies of his decision to the Capitán General and to Madrid. After selling 26 slaves, the ship sailed for Havana, regardless of the decisions adopted by the Capitán General..$^{40}$ This case exemplifies the conflicts of interests between institutions and also reveals the use of large ships in the intra-regional slave trade (Felipe, 2019). Although most of this regional trade was carried out on small and medium-sized ships, larger expeditions linking the redistribution hubs and the regions of high demand were fairly common. ${ }^{41}$

The arrival in Havana of the British frigate Blaydes on June 11, 1789 highlighted the hurdles that the new regulations could plant in the path of Baker and Dawson's ships. The ship's captain, John Simmons, at first did not allow any official to come on board to conduct an inspection. After a series of vicissitudes, the inspection finally took place, and the slaves were disembarked. ${ }^{42}$ Soon afterwards, on October 28, another Baker and Dawson frigate named the Garland, commanded by William Forbes, arrived in the same harbour. This arrival made port authorities suspicious; the Blaydes was still there, and it was feared that both ships were involved in a coordinated smuggling operation. ${ }^{43}$ The Intendente Hernani also pointed out that Baker and Dawson's ships exceeded the maximum size allowed; article 10 of the regulations specified that slave ships should be under 300 tonnes, whereas the British ships were believed to be 'able to carry 40 guns' ${ }^{44}$

The frigate Garland was also involved in a series of controversies with the authorities in Havana which considerably delayed the disembarkation and sale of the slaves it carried. After the ship's arrival, the Marquis del 
Real Socorro, one of the main slave owners in Havana, arrived at the ship to negotiate. Captain Forbes refused, however, claiming that the sale had to take place under his direct supervision. Forbes was repeatedly asked to hand over the slaves to avoid injury "to the public and to yourself". His continued refusal led the Capitán General, after consulting with Intendente Hernani, to appoint Captain Joseph de Villena to immediately begin negotiations, while also threatening to take the slaves by force if they were not handed over within the day. Finally, one and a half months after arriving in Havana, the slaves were disembarked and promptly sold. ${ }^{45}$

\section{ESTIMATED NUMBERS OF SLAVES}

The changes introduced to trade regulations prompted Baker and Dawson to try to sign a new and exclusive contract. ${ }^{46}$ Although they had some support in Havana and Caracas, neither the authorities nor the majority of citizens in Cuba and Venezuela were in favour of a new contract. Hacienda owners and merchants from Havana and Santiago de Cuba jointly emphasized that the previous asiento had not provided the expected results, that Baker and Dawson's promise to bring 5,000 or 6,000 slaves per year was not credible given their previous history, and, especially, that a monopoly contract would bring an end to the free trade system, which was yielding very good results. ${ }^{47}$ Indeed, the liberalisation policy had resulted in a constant stream of slaves that was being channelled through various ports, and finally meeting demand (see Table 2).

The liberalisation of the slave trade confirmed Cuba's role as the main slave market in the Spanish Caribbean. Over $83 \%$ of all the slaves imported as a result of this early policy of liberalisation ended up being delivered to Cuba, with Havana acting as the main port of disembarkation. Santiago de Cuba was the second most important market in the Spanish Caribbean, despite the fact that it was open only to Spanish merchants. Moreover, Santiago de Cuba was the main port of arrival for slaves brought from Jamaica, who were afterwards redistributed to Puerto Príncipe, Trinidad and Havana. This created a distribution network that satisfied the demand of enclaves along the southern coast of Cuba that were not authorised to receive

Table 2. Ships and Slaves entering the Ports of Havana, Santiago de Cuba, La Guaira, Puerto Cabello and San Juan, April 1789-December 1790.

\begin{tabular}{|c|c|c|c|c|c|c|c|}
\hline Harbour & $\begin{array}{l}\text { Nationality } \\
\text { of the ship }\end{array}$ & $\begin{array}{c}\text { Total } \\
\text { number of } \\
\text { slaves }\end{array}$ & $\begin{array}{l}\% \text { of the } \\
\text { total number } \\
\text { of slaves }\end{array}$ & $\begin{array}{l}\text { Ships sailing } \\
\text { from Africa }\end{array}$ & $\begin{array}{c}\text { Number of } \\
\text { slaves from } \\
\text { Africa }\end{array}$ & $\begin{array}{c}\text { Ships } \\
\text { sailing from } \\
\text { American } \\
\text { harbours }\end{array}$ & $\begin{array}{c}\text { Number of } \\
\text { slaves from } \\
\text { American } \\
\text { territories }\end{array}$ \\
\hline \multirow{7}{*}{ Havana $^{48}$} & Spanish & 959 & 13.2 & 0 & 0 & 27 & 959 \\
\hline & Foreign & 3,537 & 48.6 & 14 & 2,798 & 13 & 739 \\
\hline & Danish & 247 & 3.4 & 0 & 0 & 3 & 247 \\
\hline & United States & 619 & 8.5 & 5 & 582 & 1 & 37 \\
\hline & France & 557 & 7.6 & 1 & 262 & 3 & 295 \\
\hline & United Kingdom & 2,114 & 29.1 & 8 & 1,954 & 7 & 160 \\
\hline & Total & 4,496 & 61.8 & 14 & 2,798 & 41 & 1,698 \\
\hline \multirow{3}{*}{$\begin{array}{l}\text { Santiago } \\
\text { de Cuba }\end{array}$} & Spanish & 1,552 & 21.3 & 0 & 0 & 111 & 1,552 \\
\hline & Foreign & 0 & 0 & 0 & 0 & 0 & 0 \\
\hline & Total & 1,552 & 21.3 & $\mathbf{0}$ & $\mathbf{0}$ & 111 & 1,552 \\
\hline \multirow{3}{*}{ La Guaira } & Spanish & 284 & 3.9 & 0 & 0 & 10 & 284 \\
\hline & Foreign & 207 & 2.9 & 0 & 0 & 8 & 207 \\
\hline & Total & 491 & 6.8 & $\mathbf{0}$ & $\mathbf{0}$ & 18 & 491 \\
\hline \multirow{3}{*}{$\begin{array}{l}\text { Puerto } \\
\text { Cabello }\end{array}$} & Spanish & 203 & 2.8 & 0 & 0 & 12 & 203 \\
\hline & Foreign & 56 & 0.8 & 1 & 5 & 3 & 51 \\
\hline & Total & 259 & 3.6 & 1 & 5 & 15 & 254 \\
\hline \multirow{4}{*}{ San Juan ${ }^{49}$} & Spanish & 116 & 1.6 & 0 & 0 & 36 & 116 \\
\hline & Foreign & 359 & 4.9 & 0 & 0 & 37 & 359 \\
\hline & Total & 475 & 6.5 & $\mathbf{0}$ & $\mathbf{0}$ & 73 & 475 \\
\hline & Overall total & 7,273 & 100 & 15 & 2,803 & 258 & 4,470 \\
\hline
\end{tabular}

Source: AGI, Indiferente General 2822, 2823; Santo Domingo 2207; and Santo Domingo 2310. 
slaves directly, although some of these slaves were sent onward to Havana as well (Chaviano, 2014: 152-153; Belmonte, 2010: 458). For instance, the schooner San Ignacio, under the command of Pedro Salazar, sailed from Santiago de Cuba on June10, 1790. Officially, she was carrying 3,500 silver pesos fuertes and 25 pounds of tortoiseshell to buy slaves. She moored in Montego Bay, on the northern coast of Jamaica, where she embarked 46 slaves (31 men, 11 boys identified as "mulecones" and "muleques", and 4 women) before returning to Santiago, where she landed on July 2. That same day, after selling some slaves in Santiago, she sailed for Havana with 37 slaves (27 men, eight boys listed as "mulecones" and "muleques," and two women), and arrived on July18, $1790 .{ }^{50}$ Speed was of the essence for the success of these expeditions, as this kept down maintenance costs, wages and sailing expenses, as well as ensuring that the slaves arrived alive.

Santiago de Cuba also became the main centre of operations for Spanish slave dealers who specialised in the intra-American trade, surpassing Havana. In the Province of Caracas, La Guaira was much more active than Puerto Cabello, importing roughly the same number of slaves as San Juan de Puerto Rico; it is worth noting that while Spanish merchants were predominant in La Guaira, their role in San Juan was less prominent. Overall, $42.8 \%$ of all slaves arriving in all of these Spanish Caribbean ports combined during this period were imported by Spanish merchants, which reveal the existence of a solid inter-colonial mercantile structure that could successfully adapt to the new regulations. Most of these captives arrived on voyages that sailed from other ports in the Caribbean; of 273 ships that landed slaves in Spanish Caribbean ports in 1789-1790, only 15 came from Africa (see Table 3); of all the slaves imported during this period, $61.4 \%$ were brought from American harbours (Table 4). Havana successfully operated within both transatlantic and intraAmerican circuits, and maintained especially close links with Dominica, Jamaica, Saint Thomas, and even some ports in the southern United States (Borucki, Eltis and Wheat, 2015:443-445).

Santiago de Cuba, by contrast, was heavily dependent on its contacts with Jamaica; its transactions with other harbours such as Saint Domingue, Providence (Bahamas), and Saint Eustatius were sporadic. Santiago specialised in intra-Caribbean trade, which was mostly carried out by small ships bringing a few slaves at a time. To a large extent, this was because, despite the government's efforts, the slave trade was used to cover up illicit mercantile activities. ${ }^{51}$ This model of intra-colonial trade was also predominant in the remaining authorised harbours, which likewise traded primarily with other Caribbean territories. The circuit linking La Guaira and Trinidad, which was articulated during the period of the asiento, remained active although the number of slaves channelled through this circuit decreased sharply. Surpassing even Curaçao, Saint Croix, Dominica, and Saint Domingue, Trinidad remained the most important redistribution node for the Spanish Caribbean during this period, channelling its slaves through La Guaira.
Its geographical proximity to the coast of Venezuela and its pre-existing commercial relations allowed Curaçao to become the main supplier of slaves to Puerto Cabello, where demand was much smaller than that of the La Guaira-Caracas axis, and where ships arrived directly from Africa or from Saint Croix only sporadically. San Juan de Puerto Rico, on the other hand, owing to its location near a point where the frontiers of several empires converged, maintained multiple links with the Lesser Antilles in which Danish merchants from Saint Thomas played a prominent role. Spanish merchants played a secondary role in San Juan, generally buying slaves and probably other goods as well in Curaçao. The "Coast of Guinea" (probably the region around Calabar) was the point of embarkation for most enslaved people transported from Africa, who were invariably delivered to Havana. Jamaica, Dominica, Curaçao and the Danish islands of Saint Croix and Saint Thomas were the Spanish colonies' main sources of captives within the non-Hispanic Caribbean, acting as intermediary slaving hubs that redistributed captives brought via transatlantic routes.

The policy of liberalisation was a success for both the Spanish monarchy and for Spanish Caribbean slave merchants, and this led the metropolitan authorities to rule out returning to the asiento system. In February 1791, the publication of royal orders informed Caribbean governors of a six-year extension to the system of free trade. In addition, the viceroyalties of New Granada and the Río de la Plata asked to have their ports included in this lucrative business, and they, too, found a sympathetic ear in Madrid. However, the news of the revolution in Saint Domingue in August 1791 paralysed the Spanish administration. After months of deliberations, pressures, and contradictions, the main interlocutor of Havana's oligarchy, the Madrid-based Francisco de Arango y Parreño, delivered an eloquent proclamation. As a representative of the sector which had benefited the most from the liberalisation of the slave trade, Arango insisted on the need to continue with the free trade policy. This was to be the beginning of mass slavery in the Spanish Caribbean. The destruction of Saint Domingue was to be followed by a transfer of slaves, capital and qualified personnel, and the Spanish dominions would take advantage of this. Arango's manoeuvres tilted the scales (Ferrer, 2014; Piqueras, 2009a), influencing the Crown's eventual decision to extend the free trade system for another six years, authorising additional ports in Cuba and Venezuela, as well as in the viceroyalties of New Granada and Río de la Plata. ${ }^{53}$ Despite political turbulence in France, which resulted in a prohibition against trading with the Spanish Caribbean (Naranjo, 2017: 111-130; Zeuske, 2015), and despite open political tensions with the United Kingdom, the slave trade to the Spanish Caribbean continued albeit intermittently. Conflict between the various empires present in the Caribbean from 1793 onwards hampered intraCaribbean trade, and despite the succession of military defeats suffered by the Spanish navy, Spanish Caribbean slave merchants began trying in earnest to establish permanent commercial links with West Africa. However, 
10 - José Luis Belmonte Postigo

Table 3. Origin of Ships and Numbers of Slaves entering the Ports of Havana, Santiago de Cuba, La Guaira, Puerto Cabello and San Juan, April 1789-1790.

\begin{tabular}{|c|c|c|c|}
\hline Spanish harbour & Region of origin & Number of ships & Number of slaves \\
\hline \multirow{9}{*}{ Havana } & Coast of Guinea & 13 & 2,628 \\
\hline & Gold Coast & 1 & 170 \\
\hline & Charleston & 2 & 38 \\
\hline & Virginia & 1 & 21 \\
\hline & Dominica & 7 & 634 \\
\hline & Providence (Bahamas) & 5 & 117 \\
\hline & Jamaica & 23 & 641 \\
\hline & Saint Thomas & 3 & 247 \\
\hline & Total & 55 & 4,496 \\
\hline \multirow{5}{*}{ Santiago de Cuba } & Jamaica & 102 & 1,412 \\
\hline & Saint Domingue & 7 & 75 \\
\hline & Providence & 1 & 1 \\
\hline & Saint Eustatius & 1 & 64 \\
\hline & Total & 111 & 1,552 \\
\hline \multirow{8}{*}{ La Guaira } & Trinidad & 5 & 191 \\
\hline & Saint Domingue & 2 & 59 \\
\hline & Curaçao & 3 & 35 \\
\hline & Grenada & 1 & 30 \\
\hline & Dominica & 1 & 46 \\
\hline & Saint Croix & 5 & 120 \\
\hline & Saint Thomas & 1 & 10 \\
\hline & Total & 18 & 491 \\
\hline \multirow{5}{*}{ Puerto Cabello } & Curaçao & 13 & 208 \\
\hline & African coast & 1 & 5 \\
\hline & Saint Croix & 1 & 15 \\
\hline & Foreign colonies (not specified) & 1 & 31 \\
\hline & Total & 16 & 259 \\
\hline \multirow{9}{*}{ San Juan de Puerto Rico ${ }^{52}$} & Antigua & 3 & 30 \\
\hline & Curaçao & 16 & 49 \\
\hline & Saint Domingue & 2 & 9 \\
\hline & Saint Eustatius & 9 & 25 \\
\hline & Saint Croix & 23 & 260 \\
\hline & Santiago de Cuba & 1 & 4 \\
\hline & Saint Thomas & 18 & 95 \\
\hline & Trinidad & 1 & 3 \\
\hline & Total & 73 & 475 \\
\hline
\end{tabular}

Sources: AGI, Indiferente General 2822, 2823; Santo Domingo 2207; and Santo Domingo 2310. 
Table 4. Origin of Slaves entering the Ports of Havana, Santiago de Cuba, La Guaira, Puerto Cabello and San Juan de Puerto Rico, April 1789-1790.

\begin{tabular}{|c|c|c|c|c|}
\hline Region of origin & Number of slaves & $\%$ & Number of ships & $\%$ \\
\hline Coast of Guinea & 2,628 & 36.1 & 13 & 4.8 \\
\hline Jamaica & 2,053 & 28.2 & 125 & 45.8 \\
\hline Dominica & 680 & 9.3 & 8 & 2.9 \\
\hline Saint Croix & 395 & 4.9 & 29 & 10.6 \\
\hline Saint Thomas & 352 & 4.4 & 22 & 8 \\
\hline Curaçao & 292 & 3.7 & 32 & 11.7 \\
\hline Trinidad & 194 & 2.4 & 6 & 2.2 \\
\hline Gold Coast & 170 & 2.1 & 1 & 0.4 \\
\hline Saint Domingue & 143 & 1.8 & 11 & 4 \\
\hline Providence (Bahamas) & 118 & 1.5 & 6 & 2.2 \\
\hline Saint Eustatius & 89 & 1.1 & 10 & 3.6 \\
\hline Charleston & 38 & 0.5 & 2 & 0.7 \\
\hline Foreign colonies (not specified) & 31 & 0.4 & 1 & 0.4 \\
\hline Grenada & 30 & 0.4 & 1 & 0.4 \\
\hline Antigua & 30 & 0.4 & 3 & 1.1 \\
\hline Virginia & 21 & 0.3 & 1 & 0.4 \\
\hline African Coast & 5 & 0.1 & 1 & 0.4 \\
\hline Santiago de Cuba & 4 & 0.1 & 1 & 0.4 \\
\hline Total & 7,273 & 100 & 273 & 100 \\
\hline
\end{tabular}

Source: AGI, Indiferente General 2822, 2823; Santo Domingo 2207; and Santo Domingo 2310.

Spanish merchants in Cuba and Puerto Rico only managed to achieve this from 1808 onwards, when the Spanish colonial system began to collapse.

\section{ACKNOWLEDGEMENTS}

The author is grateful to Alex Borucki, Martín Rodrigo Alharilla and David Wheat, whose comments on the draft of this work greatly contributed to its final shape.

Research carried out within the framework of Research and Innovation Staff Exchange (RISE) H2020MSCA-RISE-2018:ConnecCaribbean-823846, 20192022 and the MINECO-funded programme Mercados $y$ tratas de esclavos en el Atlántico ibérico del siglo XVI, HAR-2016-78056-P.

\section{NOTES}

1 According to slavevoyages.org (http://www.slavevoyages.org/ voyage/82810/variables), this expedition was successful and ended with the sale of the slaves at La Guaira. However, as we shall see, the sale of the 453 slaves on board did not take place in Venezuela.

2 The Baker and Dawson trading house was the most important Atlantic slave trading firm between 1783 and 1792 (Behrendt, 1990:104).

3 Carmen Barcia points out that most of the slaves who arrived in Cuba after 1773 came from Jamaica (Barcia, 2016:59).
4 Archivo General de Indias (AGI), Santo Domingo 2283: letter from the governor Miguel de Nuesas to the Council of the Indies. San Juan, 3 May 1776.

5 AGI, Santo Domingo 2283: decree by the Council of the Indies. Madrid, 7 May 1779.

6 AGI, Santo Domingo 983: report by the governor and the royal officials in Santo Domingo, explaining that the number of smuggled slaves was too high. Santo Domingo, 24 February 1773.

7 AGI, Indiferente General 2821: Eduardo Barry, a dealer from Jamaica, as a member and legal representative of Fitch and Company sets conditions for an import asiento for negroes from the island of Trinidad. El Pardo, 13 February 1784.

8 The relationship between Barry \& Black and Baker and Dawson ended up in court. The default of some payments related to 'slaves and other trade goods' led Baker and Dawson to sue Barry \& Black. In 1787, the Spanish authorities confiscated and auctioned the company's and the agents' property, in order to satisfy the debt with the proceedings. When the confiscation took place, Barry \& Black owed nearly 100,000 pesos. AGI, Indiferente General 2824: Baker and Dawson's claim against Eduardo Barry and Juan Black. San Lorenzo, 24 October 1788.

9 AGI, Indiferente General 2824: Governor Chacón reports on the actions undertaken between the Intendente of Caracas and the Audiencia. Isla Trinidad, 18 July 1793.

10 AGI, Indiferente General 2824: the Intendente de Ejército in Havana reports on the arrival of Baker and Dawson's first asiento ship. Havana, 7 July 1786. The monarchy had established a single account to pay for the slaves sold under the contract. The account was based in Havana and was funded from New Spain.

11 AGI, Santo Domingo 2588: decree by H.M. which regulates settlement and trade in the island of Trinidad de Barlovento. San Lorenzo, 24 November 1783. 
12 The agreement recognised the right of the Spanish authorities to confiscate other cargoes found during their inspections. Baker and Dawson tried to include ivory tusks and palm oil in the agreement, and argued that they were also African goods. AGI, Indiferente General 2824: reply from Baker and Dawson to Bernardo del Campo about the negro contract. Liverpool, 23 January 1786

13 AGI, Santo Domingo 2824: the Intendente of Caracas confirms reception of royal order of 20 July about negro cargoes. Caracas, 20 October 1786.

14 AGI, Indiferente General 2824: the Intendente de Ejército in Havana replies to the royal order of 20 July, committing to pay for the Negroes subject to the asiento granted to Baker and Dawson and sold in Havana and Santo Domingo. Havana, 10 October 1786

15 This agreement also implied the cancellation of the personal licences granted, especially after America's War of Independence. AGI, Indiferente General 2821: Royal order of 22 April 1786 revoking personal licences for the import of slaves.

16 Despite Barry \& Black's attempts to continue acting as the company's agents. Baker and Dawson sent a new agent to Caracas, Philip Langton. AGI, Indiferente General 2824: the Intendente of Caracas explains the reasons it accepted the arrival of negro cargoes belonging to Baker and Dawson. Caracas, 11 June 1786.

17 The arrival of the first ship, the Héroe, predated the arrival of the orders concerning the asiento. As such, the Intendente of Havana ruled out paying for the slaves with public funds, as was customary when the previous contract was in force. The proceedings came from the public auction of the slaves, with the consent of the captain of the slave ship, William Forbes, who insisted on conducting the auction himself. AGI, Indiferente General 2824: the Intendente de Ejército in Havana reports on his decision to let the English captain sell the Negroes as he pleased, subject to the Baker and Dawson asiento. Havana, 20 July 1786.

18 AGI, Indiferente General 2824: signed copy of the contract with Pedro Baker and Juan Dawson. London, 1 May 1786.

19 AGI, Santo Domingo 949: report from the Capitán General of Santo Domingo, Joaquín García. Santo Domingo, 25 August 1789.

20 AGI, Indiferente General 2824: the governor of Havana forwards a statement by hacienda owners which insists on a petition issued by the Junta Central de negros. Havana, 3 January 1789.

21 AGI, Indiferente General 2824: the Intendente de Ejército of Havana replies to the royal order of 31 August 1787. Havana, 2 January 1788. At the end of this extension, three Baker and Dawson ships were allowed to enter Spanish harbours, the Princesa Real, the Garland and the brig Joven Héroe, where they enjoyed the same conditions as when the asiento was in force. AGI, Indiferente General 2824: royal order of 18 June 1788 , permitting access to three ships belonging to Baker and Dawson, after the end of the extension.

22 The Mosley Hill left Bonny with 736 slaves, heading to La Guaira, where she delivered 674. Afterwards, she sailed to Havana to sell the remaining slaves. Strangely, the sale of only eight slaves is recorded there, raising questions about the real nature of this voyage and the real number of slaves sold. It is possible that the accusations levelled at Baker and Dawson for carrying out irregular commercial activities were, to some extent, true. The trip to Havana is not recorded in slavevoyages. org (http://www.slavevoyages.org/voyage/82808/variables).

23 This expedition is described differently on slavevoyages.org. There is a record of a voyage which began in Bonny and ended at an unspecified point in the Spanish Caribbean with the sale of 328 slaves. The beginning and end dates would have been 15 May 1788 and 2 April 1789:http://www.slavevoyages.org/voyage/81551/variables. The end date suggests that the expeditions referred to on slavevoyages.org and in AGI are, indeed, the same expedition, although the number of slaves delivered and the final destination do not coincide.
24 Both this ship and the next on the list, the Héroe, arrived in Havana after the liberalisation of the slave markets, but were allowed to carry out their expedition under the same conditions that had applied when the asiento was in force.

25 AGI, Indiferente General 2822: Francisco Antonio de Astigarreta, administrator of the royal accounts in Havana, certifies the balance of the contract with Liverpudlian merchants Pedro Baquer and Juan Dawson. Havana, 23 May 1789. Twenty-seven slaves died while awaiting disembarkation and, therefore, Astigarreta did not include them in his statistics.

26 AGI, Indiferente General 2822: Francisco Antonio de Astigarreta, administrator of the royal accounts in Havana, certifies the balance of the contract with Liverpudlian merchants Pedro Baquer and Juan Dawson. Havana, 23 May 1789. Although Astigarreta records accounts for all arrivals, only the gender of the rejects is recorded, and no conclusions may be drawn concerning age groups and physical condition.

27 AGI, Indiferente General 2824: the Intendente de Ejército of Havana sends a copy of the proceedings of the meeting celebrated after the arrival of the first negro cargo by Baker and Dawson. [Havana], 13 October 1786. The Intendente pointed out that, "in the next ones, we can only accept one-third of females and two-thirds of males, which is the customary proportion, and because females are less in demand, and will be hard to sell".

28 AGI, Indiferente General 2824:the Intendente de Caracas replies to the royal order of 22 February 1787, establishing that Baker and Dawson's cargoes contain no females. Caracas, 31 May 1787.

29 AGI, Indiferente General 2824: communication by Messrs. Baker and Dawson, Liverpool (England) merchants, to H.M. with the intercession of the Marquis del Campo, plenipotentiary minister of H.M. in London. Liverpool, 30 October 1787.

30 AGI, Indiferente General 2824: the Intendente de Ejército of Havana sends certified copy of the Junta de Real Hacienda. Havana, 8 August 1786.

31 AGI, Indiferente General 2822:decision by the Junta Suprema de Estado. Madrid, 10 February 1789.

32 AGI, Indiferente General 2822: List ships loaded with Negroes ships arriving to Havana. Havana, 13 October 1790 andAGI, Santo Domingo 2207.

33 AGI, Indiferente General 2821: royal decree of 28 February 1789 .

34 AGI, Indiferente General 2822: the governor of Santo Domingo, Joaquín García, demands clarification concerning some doubts with regard to article eight of the royal decree of $28 \mathrm{Feb}-$ ruary 1789. Santo Domingo, 25 February 1790.

35 AGI, Santo Domingo 2310:report on compliance of the royal decree of 1789 concerning the arrival of negros, their number and other related matters. San Juan, 3 March 1791.

36 In addition to silver, in Santiago de Cuba, mules, cattle, sugar, red wine, liquor, olives and many other products, including yarey hats, were used to pay for slaves. These forms of payment included not only local products but also European goods, which were now widely available in the Caribbean after the new commercial regulations of 1778 . This expanded supply chiefly benefited intra-regional trade (Belmonte, 2012:168-169).

37 AGI, Indiferente General 2822: Intendente Guillelmi, from Caracas, asks 12 questions about the royal decree of 28 February 1789. Caracas, 9 August 1791.

38 AGI, Indiferente General 2826: the Intendente de Ejercito in Havana sends a copy of the Junta about the negro tax. Havana, 8 June 1789.

39 AGI, Indiferente General 2826:Junta Suprema de Estado. Madrid, 11 January 1790 .

40 El Soberbio arrived in Havana in February 1790 and sold 190 slaves. AGI, Indiferente General 2822: list of ships loaded with negroes arriving in Havana. Havana, 13 October 1790.

41 The French ship La Juana, again from Dominica, also arrived in Havana in February 1790, with 102 slaves. AGI, Indiferente General 2822: list of ships loaded with negroes arriving in Havana. Havana, 13 October 1790. 
42 AGI, Indiferente General 2822: the Intendente de Ejercito of Havana reports the arrival on June 11 of an English frigate with negroes. Havana, 6 July 1789.

43 Article 11 of the regulations established that foreign ships should remain in the ports only for as long as it took to disembark and sell the slaves, after which the ships should set sail within 24 hours.

44 AGI, Indiferente General 2822: the Intendente de Ejercito of Havana reports the arrival of a ship, belonging to Baker and Dawson, with negroes. Havana, 9 November 1789. The royal decree of 8 March 1791 increased the maximum allowed size to 500 tons.

45 AGI, Indiferente General 2822:the Gobernador Interino of Havana reports on the incident that occurred with the English frigate Garland. Havana, 11 December 1789

46 AGI, Indiferente General 2822: El Gobernador de Habana Luis de las Casas sends proposal presented by Baker and Dawson to introduce 5,000 or more African negroes. Havana, 27 March 1791.

47 AGI, Indiferente General 2822: declaration of the citizens and hacienda owners from Havana. Havana, 30 December 1790.

48 Only the records from Havana specify the flag under which ships sailed. In the other harbours, the records indicate only whether the ship was Spanish or foreign.

49 The figures corresponding to Puerto Rico cover the period between 1 January and 31 December 1790

50 AGI, Indiferente General 2823: list of the slave ships leaving Santiago de Cuba, Santiago de Cuba, 30 June 1792; AGI, Indiferente General 2822: list of slave ships entering Havana. Havana, 13 October 1790 .

51 In 1792, the governor of Santiago de Cuba was harshly reprimanded by Madrid because of the 'scandalous contraband' from Jamaica, shipped under the umbrella of the slave trade. AGI, Indiferente General 2823: royal decree of 24 October 1792, to the governor of Cuba.

52 The figures corresponding to Puerto Rico cover the period between 1 January and 31 December 1790.

53 Harbours authorised after the extension of the system included Buenos Aires, Montevideo, Puerto Cabello, La Guaira, Maracaibo, Cumaná, Nueva Barcelona, Santo Domingo, San Juan de Puerto Rico, Cartagena and Havana. Ports open to Spanish slave dealers were Nuevitas, Batabanó, Santiago de Cuba, Trinidad and Riohacha. AGI, Indiferente General 2822:royal decree authorising the free slave trade in the viceroyalties of Santa Fe, Buenos Aires, Capitanía General of Caracas and the islands of Santo Domingo, Cuba and Puerto Rico, to Spanish and foreign dealers under the attached rules. San Lorenzo, 24 November 1791.

\section{REFERENCES}

Aizpurúa, Ramón (2008) «Esclavitud, navegación y fuga de esclavos en el Curazao del siglo XVIII» in Dalla Corte, Gabriela, García Jordán, Pilar, Laviña, Javier et. al. Poder local poder global en América Latina, Servicio de Publicaciones de la Universidad de Barcelona, Barcelona: 81-94.

Barcia, $M^{a}$ del Carmen (2016) «La trata negrera inter-caribeña y la región oriental» Revolución y Cultura, No 2, abril: 58-63.

Behrendt, Stephen D. (1990) «The Captains in the British Slave Trade from 1785 to 1807» Transactions of the Historic Society of Lancashire and Cheshire, Vol, 140: 79-140.

Belmonte Postigo, José Luis (2010) «Brazos para el azúcar, esclavos para vender. Estrategias de comercialización en la trata negrera de Santiago de Cuba, 1789-1794». Revista de Indias, Vol. LXX, No 249: 445-468.

Belmonte Postigo, José Luis (2012) Ser esclavo en Santiago de Cuba. Espacios de poder y negociación en un contexto de expansión y crisis, 1780-1803. Editorial Doce Calles, Madrid.

Belmonte Postigo, José Luis (2016) «Bajo el negro velo de la ilegalidad. Un análisis del mercado de esclavos dominicano, 1746-1821», Nuevo Mundo Mundos Nuevos, puesto en línea el 7 de julio de 2016, https://journals.openedition.org/nuevomundo/69478.
Belmonte Postigo, José Luis (2017) «No siendo lo mismo echarse a la mar, que es lugar de libertad plena. Cimarronaje marítimo y política transimperial en el Caribe español, 1687-1804», In Naranjo Orovio, Consuelo, Esclavitud y diferencia racial en el Caribe Hispano, Editorial Doce Calles, Madrid: 43-70.

Borucki, Alex (2012) «Transimperial History in the Making of the Slave Trade to Venezuela, 1526-1811». Itinerario, Vol. XXXVI, Issue 2: 29-54

Borucki, Alex, Eltis, David, Wheat, David (2015) «Atlantic History and the Slave Trade to Spanish America». American Historical Review, Vol. 120, No 2: 433-461.

Caamaño Dones, Josué (2012), «Sociedad». In González Vales, Luis y Luque, María Dolores, Historia de Puerto Rico. Editorial Doce Calles, Madrid: 195-224.

Cassá, Roberto (2003) Historia económica y social de la República Dominicana, Tomo I, Editora Alfa \& Omega, Santo Domingo.

Chaviano, Lisbeth (2013), Trinidad, una historia económica basada en el azúcar, Tesis Doctoral inédita, Universidad Pompeu Fabra.

De la Fuente, Alejandro (2009), «Esclavitud 1510-1886». In Naranjo, Consuelo, Historia de Cuba. Editorial Doce Calles, Madrid: 129-152.

Donoso Anes, Rafael (2007) «Un análisis sucinto del Asiento de esclavos con Inglaterra (1713-1750) y el papel desempeñado por la contabilidad en su desarrollo». Anuario Estudios Americanos, Vol. 64, No2: 105-144.

Felipe González, Jorge (2019 forthcoming) «Reassessing the Slave Trade to Cuba». In Borucki, Alex, Eltis, David and Wheat, David (eds.), From the Galleons to the Highlands: Slave Trade Routes in the Spanish Americas, University of New Mexico Press, Albuquerque.

Ferrer, Ada (2014), Freedom's Mirror. Cuba and Haiti in the Era of Revolution. Cambridge University Press, Cambridge.

Fuentes, Marisa J. (2016) Dispossessed Lives. Enslaved Women, Violence and the Archive, University of Pennsylvania Press, Philadelphia.

García Cantús, María Dolores (2004) Fernando Poo, una aventura colonial española en el Africa occidental, 1778-1900, Tesis Doctoral, Servicio de Publicaciones de la Universidad de Valencia, Valencia.

García Rodríguez, Mercedes (2008) «Los ingleses en el tráfico y comercio de esclavos en Cuba (1715-1739)». Ciências \&Letras, 44, (jul-dez): 189-214.

Gutiérrez Escudero, Antonio (2010) «La estructura económica de Santo Domingo 1500-1795». In Moya Pons, Frank, Historia de la República Dominicana, Editorial Doce Calles, Madrid: 5794.

Gutiérrez Escudero, Antonio (2011) «El tabaco de Santo Domingo y su exportación a Cádiz y Sevilla (siglos XVI-XVIII)». Revista Hispanoamericana. Revista Digital de la Real Academia Hispano Americana de Ciencias, Artes y Letras, $\mathrm{N}^{\circ}$ 1: 1-13.

Karras, Alan (2007) «Transgressive Exchange. Circumventing Eighteenth-Century Atlantic Commercial Restrictions, or the Discount of Monte Christi». In Bentley, Jerry, Bridental, Renate and Wigen Kären, Seascapes. Maritime Histories, Littoral Cultures, and Transoceanic Exchanges, University of Hawaii Press, Honolulu: 121-134

Lovejoy, Paul and Richardson, David (1999) «Trust, Pawnship and Atlantic History. The Institutional Foundations of the Old Calabar Slave Trade». The American Historical Review, Vol. 104, $\mathrm{N}^{\circ} 2: 332-355$.

Moya Pons, Frank (2008), Manual de Historia Dominicana, Caribbean Publishers, Santo Domingo.

Naranjo, Consuelo (2017) «Represión, miedo y raza en Puerto Rico y Cuba, 1789-1839». In Naranjo, Consuelo (ed.), Esclavitud y diferencia racial en el Caribe Hispano, Editorial Doce Calles, Aranjuez: 111-130.

Nwawa, A.O. (1990) «The Dating of the Aro Chiefdom: A Synthesis of Correlated Genealogies». History in Africa, Vol. 17: 227245.

Nwokeji, Ugo (2010) The Slave Trade and Culture in the Bight of Biafra. Cambridge University Press, New York. 
O'Malley, Gregory (2014) Final Passages. The Intercolonial Slave Trade of British America, 1619-1807. University of North Carolina Press, Williamsburg.

O'Malley, Gregory and Borucki, Alex (2017) «Patterns in the Intercolonial Slave Trade Across the Americas Before the Nineteenth Century». Revista Tempo, Vol. 23, No2, Mayo/Agosto: 314-338.

O'Shaughnessy, Andrew Jackson (2000) An Empire Divided. The American Revolution and the British Caribbean. University of Pennsilvania Press, Philadelphia.

Pearce, Adrian (2014) British Trade with Spanish America 17631808. Liverpool University Press.

Piqueras, José Antonio (2009a) «Los amigos de Arango en la corte de Carlos IV». In González Ripoll y Álvarez Cuartero Izaskun (eds.), Francisco de Arango y la invención de la Cuba azucarera, Universidad de Salamanca, Salamanca: 151-166.

Piqueras, José Antonio (2009b) «La vida política entre 1780 y 1878». In Naranjo, Consuelo (coord.), Historia de Cuba. Editorial Doce Calles, Madrid: 273-302.

Piqueras, José Antonio y Vidal, Emma (2018) «Los británicos en el comercio de esclavos de Cuba». In Cózar, María del Carmen y Rodrigo y Alharilla, Martín (eds.), Cádiz y el tráfico de esclavos. De la legalidad a la clandestinidad. Editorial Sílex, Madrid.

Quintero, Inés (2013) «De cómo las esclavas obtienen su libertad. Venezuela siglo XVIII». In Laviña, Javier, Piqueras, Ricardo y Mondéjar, Cristina, Afroamérica, espacios e identidades. Editorial Icaria, Barcelona: 240-256.

Rawley, James A. and Behrendt, Stephen D. (2005) The Transatlantic Slave Trade, A History. Nebraska University Press, Lincoln and London.
Rupert, Linda (2013) «Seeking the Waters of Baptism”. Fugitive Slaves and Imperial Jurisdiction in the Early Modern Caribbean». Ross, Richard and Benton, Lauren, Legal Pluralism and Empires. New York University Press, New York: 199232.

Schneider, Elena (2015) «African Slavery and Spanish Empire. Imperial Imaginings and Bourbon Reform in Eighteenth-Century Cuba and Beyond». Journal of Early American History, N5: $3-29$.

Schneider, Elena (2019 forthcoming) «Routes into Eighteenth-century Cuban Slavery: African Diaspora and Geopolitics»). In Borucki Alex, Eltis, David, and Wheat, David (eds.) From the Galleons to the Highlands: Slave Trade Routes in the Spanish Americas. University of New Mexico Press, Albuquerque.

Sevilla Soler, Rosario (1981) «El comercio entre Santo Domingo y Andalucía, 1750-1795». Primeras Jornadas sobre Andalucía y América, Vol. 1: 138-148.

Tornero Tinajero, Pablo (1996), Crecimiento económico y transformaciones sociales. Esclavos, hacendados y comerciantes en la Cuba colonial (1760-1840). Ministerio de Trabajo y Seguridad Social, Madrid.

Widmer, Rudolph (2003) «El Hato ganadero del Este en la economía de Santo Domingo en el siglo XVIII. Con Antonio Sánchez Valverde en San Dionisio de Higüey». Clío, Órgano de la Academia Dominicana de la Historia, Santo Domingo, N ${ }^{\mathrm{o}}$ 165, enero-junio: 143-159.

Zeuske, Michael (2015) «The French Revolution in Spanish America». In Forrest, Alan y Middle, Mathias (eds.), The Routledge Companion to the French Revolution in World History, Routledge, London and New York: 77-96. 